\title{
Tea export competitiveness and the nexus between tea export and economic growth: The cases of Bangladesh, India and Sri Lanka
}

Long since the end of the British India regime, Bangladesh, India, and Sri Lanka have produced a significant volume of tea which continues to bring them invaluable foreign currency earnings through exports. Our paper explores the tea export competitiveness of these countries by employing the Revealed Symmetric Comparative Advantage (RSCA) index, and analyses the nexus between tea export and economic growth over the period from 1980 to 2018 using several dynamic econometric approaches. Results suggest that Bangladesh has lost its tea export competitiveness over the last decade. India posted moderate performance, while Sri Lanka consistently kept its dominant position. Further, the Johansen Cointegration test outcomes report no long-run relationship between tea export and economic growth across all the countries. The Granger Causality outcomes illustrate that only in Sri Lanka is it the case that tea export causes short-run economic growth. Lastly, the impulse response function projects tea export and economic growth, taking into consideration the response of each to a shock from the other. Extrapolation from the results indicate that, in contrast to the cases of Bangladesh and India (where no direct relationship was found), tea export and economic growth are intimately interconnected in Sri Lanka. This article further recommends effective policies so that economic growth in these countries can remain steady and that their tea industries can thrive.

Keywords: tea export, competitiveness, economic growth, Asia JEL classifications: F14, O11, Q17

\footnotetext{
* Faculty of Agricultural Economics \& Rural Sociology, Bangladesh Agricultural University, Mymensingh-2202. Bangladesh. Corresponding author: sayem6738@gmail.com

** Department of Agricultural Finance and Banking, Bangladesh Agricultural University, Mymensingh-2202. Bangladesh.

Received: 6 February 2021, Revised: 23 March 2021, Accepted: 25 March 2021
}

\section{Introduction}

Over the years, tea has become one of the golden egg spawning cash-crops throughout the world due to its taste and widespread acceptance by the global public. More exactly, exporting tea from major tea-producing countries has become important to the economy and provides a crucial export earning source (Gunathilaka and Tularam, 2016). In the modern era, economic activities encompassing the tea sector have tremendously extended. Notably, the tea industries not only bring foreign currencies, but they also create jobs for vulnerable populations (Jannat, 2017). In addition to economic benefits, tea plantations also provide other essential ecosystem services such as carbon sequestration (Kamau et al., 2008). The export competitiveness of tea has burgeoned in recent years, affecting the degree of participation of the industry in internal trade (Fetscherin et al., 2010). Tea export competitiveness can be achieved if a country produces and exports a vast amount of tea and produces the best quality tea with a comparative advantage. Otherwise, the global customer will lose its appetite for the tea, and tea export competitiveness will diminish for that particular country.

The tea industry alone contributes $1 \%$ of the GDP of Bangladesh (BTB, 2017), while it accounts for 3\% of total world tea production, meaning that the country ranks as the 10th largest tea producer in the globe (Asiatic Society of Bangladesh, 2014). Bangladesh's most adjacent neighbours, India and Sri Lanka are some of the largest tea producers. However, India contributed $21 \%$ of world tea production in 2017 (FAOSTAT, 2017). Besides, the tea industry is also the second-largest source of employment in India, providing livelihoods for more than 3.5 million individuals (Tea Board of India, 2014). For Sri Lanka, the tea industry plays a significant role in the Sri Lankan economy and it contributes 0.7 percent to the national GDP (CBSL, 2019). The tea industry accounted for $15 \%$ of total exports in 2018 and provides one million workplaces in Sri Lanka (Hilal, 2020). However, the tea export volume of Sri Lanka has cumulatively decreased by $3.63 \%$ for the period of 2014-2018 and the country's percentage share of world exports has dwindled to $14.7 \%$ in 2018 from 17.3\% in 2009 (CBSL, 2019). In contrast, other major exporting countries, namely India, China and Kenya have increased their tea export value due to globalisation and their respective tea industries' competitiveness.

It should also be mentioned that very few countries are blessed with a suitable climate and apposite landscapes for tea cultivation - Bangladesh, India and Sri Lanka are among these countries. Due to their unique climate, favourable soil quality and the accessibility of different vastly demanding varieties of tea, the majority of tea producing countries are located in Asia, especially India, Sri Lanka and Bangladesh (Basu Majumder et al., 2010). Moreover, Bangladesh, India and Sri Lanka, jointly the former British India, are of same geographical region, occupying more or less comparable socio-economic positions. Henceforth, this study focuses on these counties to address the research objectives, taking into account that all of these nations possess a historic reputation for tea production and that the tea industry constitutes an indispensable part of their economy. Undoubtedly, tea adds significant appreciation in the value chain and grants employment opportunities to millions of 
people in this Indian sub-continent region which, in turn, boosts the income of the economy.

The export of agricultural products attracts policymakers' attention because it is a significant source of foreign exchange earnings, plus a catalyst for crop diversification and a rise in farm income (Suresh and Mathur, 2016). Given the significance of tea in the economy of Bangladesh, India and Sri Lanka, the extent to which these countries have a comparative advantage in the international market deserves to be explored. Also, the consequences of tea export for the overall economy need to be empirically addressed. Recognising the importance of tea and tea export in the economies of Bangladesh, India and Sri Lanka, we therefore aimed to explore the export competitiveness of tea and analyse the nexus between tea export and economic growth. This study contributes to the literature in the following ways: (a) it is the first endeavour, to the best of the authors' knowledge, to assess the tea export competitiveness of the aforementioned countries while at the same time analysing the nexus between tea export and economic growth using secondary data; (b) it assesses the comparative advantage of the tea exports of these counties, helping them to recognise their competency and position in world trade and (c) the novelty of this paper lies in the adoption of newly introduced RSCA index and application of dynamic econometric approaches to determine relationship between tea export and economic growth.

The paper is organised as follows: Section 2 represents the relevant literature review; Section 3 describes the data and the methodology used in this study, Section 4 presents the empirical results to address the objectives of this study and finally, Section 5 concludes.

\section{Literature Review}

From a theoretical perspective, it is generally assumed that exports support the economy. Being competitive in export brings in more foreign currency. Export competitiveness and export-led economic growth hypotheses are frequently discussed in the literature. Thus, the literature review is divided into two sections.

\section{Export competitiveness of tea and other agricultural products}

The theory of competitiveness is vastly adopted in neoteric economic literature to assess the shapes of trade and specialisation of nations in products that enjoy a competitive advantage (Saboniene, 2009). The export competitiveness of various agricultural products has been widely explored in recent years (e.g. Juhász, 2013; Török and Jámbor, 2013; Shalbuzov, 2020). Rahardjo et al. (2020) tried to investigate the competitiveness of Indonesian coffee in the international market by using Revealed Comparative Advantage (RCA) index and Export Product Dynamics (EPD). Results indicated that low value of RCA implying the comparative advantage of Indonesia still needs to be improved because of losing opportunities to be able to trade with other countries. Török et al. (2020) revealed that the level of comparative advantage of beer has substantially changed over three decades due to per capita beer production and consumption, the number of beers with geographical indications, and European Union (EU) membership. Likewise, Török and Jámbor (2016) reported that quality of production area and EU accession affect the competitiveness for ham trade of Europe.

In this same manner, tea, being one of the most significant agricultural export items, has attracted the attention of researchers who have begun to shed light on its international competitiveness in the context of different regions. The study of Nugrahaningrum et al. (2020), adopting Trade Specialization Index (ISP), RCA, CMS and Diamond Porter Theory confirmed that Indonesian tea has strong competitiveness in the international market. Jin (2019) attempted to measure the competitiveness of Chinese tea export in comparison to other major tea exporting countries. The outcome of RCA showed that although China enjoys a comparative advantage in tea export, it ranks lower compared to other countries. Hong and Song (2015), employing Revealed Comparative Advantage index exhibited that Fujian is well dominant in the international tea market. A similar kind of study attempted by Sachitra (2016), based on the partial least squares structural equation model, showed that government support, brand loyalty, and the state of demand have also positively influenced the export competitiveness of Sri Lanka's tea industry. Where the stability rate of tea export from India are concerned, Adhikary and Maity (2010) found instability indices are the highest for Iran and the lowest for the USA.

\section{Agricultural export and economic growth nexus}

Export-led growth hypothesis is historically of great concern in the field of economics. The hypothesis claims that with the expansion of exports, the economy of a nation grows. In developing economies, agricultural exports, alongside non-agricultural exports, drive long-term economic growth (Sanjuán-López and Dawson, 2010). Barros Jr. et al. (2019) in their investigation extrapolated that coffee which is believed to be a substitute of tea stimulates the economy of Brazil through fostering industrialisation, a position which validates the export led-growth hypothesis. Gilbert et al. (2013), who adopted an Engle Granger cointegration test, confirmed that coffee and bananas have played a significant role in accelerating economic growth in Cameroon. Similarly, Faridi (2012), by employing the Johansen Cointegration technique, revealed that agricultural exports have propelled the economic growth of Bangladesh.

Although numerous studies have accentuated the linkage between agricultural export and economic growth (e.g. Canchari et al., 2018; Shah et al., 2015; Dawson, 2005), rarely has any study set out to investigate the connection between tea export and economic growth. However, Chantal et al. (2018) studied the impact of the tea, coffee, and flowers export in Rwanda using multiple regression analysis. The study found that tea export positively affects economic growth. Muthamia and Muturi (2015), by adopting the Cointegration model and the Vector autoregressive (VAR) model, revealed that a direct relationship exists between tea export earnings and agricultural value-added. However, in recent years no research has been conducted to evaluate the 
competitiveness of tea exported from Bangladesh, India and Sri Lanka. Furthermore, no study has attempted to assess the interrelationship between tea export and the economic growth of Bangladesh, India, and Sri Lanka. Hence, this paper aims to fill these research gaps.

\section{Methodology}

Secondary data covering the period from 1980-2018, retrieved from FAOSTAT and World Bank, were employed for this research. Table 1 depicts an overview of data. In line with previous studies (Canchari et al., 2018; Olayungbo and Quadri, 2019), Real Gross Domestic Product proxied economic growth.

The Revealed Symmetric Comparative Advantage (RSCA) (Laursen, 2015) index was adopted to derive the competitiveness of tea export. This index is an updated and symmetric form of Balassa's Revealed Comparative Advantage (RCA) index (Balassa, 1965). RSCA index is the best tool for analysing comparative advantage (Laursen, 2015). It is widely applied in recent studies (e.g. Rossato et al., 2018; Naseer et al., 2019).

The equational representation of RCA is as follows:

$$
R C A_{i j}=\left(x_{i j} / x_{i t}\right) /\left(x_{w j} / x_{w t}\right)
$$

where $\mathrm{RCA}_{i j}$ stands for revealed comparative advantage of country $i$ for a product $j$ and $x_{i j}$ denotes total export of country $i$ in product $j$. Subscript $w j$ represents the world export of product $j$, and subscript wt refers to the total export of all products across the world.

The equational representation of RSCA is as follows:

$$
R S C A=(R C A-1) /(R C A+1),
$$

The value of the RSCA index ranges from -1 to 1 . RSCA $>0$ implies that a country enjoys a comparative advantage in the product that it exports, whereas RSCA $<0$ indicates otherwise.

This study also tests the survival and stability rate of the RSCA index using STATA software. Following Török and Jámbor (2016), the value of standard deviation of RSCA index over the period was used to check the stability of RSCA index. Higher value of standard deviation means unstable variation from year to year and vice versa. Moreover, following Bojnec and Fertö (2016), a survival function $S(t)$ can also be calculated through employing the thenonparametric Kaplan-Meier product limit estimator. Following
Bojnec and Fertő (2016), a sample having $\mathrm{n}$ independent observations stand for $(t i ; c i)$, where $i=1,2, \ldots, n$, and $t i$ indicates the survival time. And $c i$ denotes the censoring indicator variable $C$ (considering the value of 1 if a failure appeared, and 0 otherwise) of observation $i$. Let, $n j$ denotes the number of subjects at failing risk at $t(j)$ and $d j$ indicates the number of failures observed. The Kaplan-Meier estimator of the survival function is then (with the convention that $\hat{S}(t)=1$, if $t<t(1))$ :

$$
\hat{S}(t)=\prod_{t(i)<t} \frac{n_{j}-d_{j}}{n_{j}},
$$

After exploring tea export competitiveness, we moved on to investigating the nexus between tea export and economic growth. Prior to operating the Johansen Cointegration approach, we ran the Augmented Dickey-Fuller (ADF) test to check the stationarity of the series employed. The equational representation goes as:

$$
\begin{aligned}
& \Delta Y_{t}=\mu+\delta Y_{t-1}+\beta_{1} \Delta Y_{t-1}+ \\
& +\beta_{2} \Delta Y_{t-2}+\ldots+\beta_{p} \Delta Y_{t-p}+\varepsilon_{t}
\end{aligned},
$$

where $\mathrm{H}_{0}: \delta=0$, up against $\mathrm{H}_{1}: \delta$. Rejection of $\mathrm{H}_{0}$ means the series is stationary, whereas accepting $\mathrm{H}_{0}$ denotes series is non-stationary.

The Johansen cointegration test (Johansen, 1991) can only be applied if all the variables are stationary at $1^{\text {st }}$ difference. It takes its starting point in the vector autoregression (VAR) of order $P$ given by the following equation:

$Y_{t}=\mu+A_{1} Y_{t-1}+\ldots+A_{p} Y_{t-p}+\varepsilon_{t}$,

where $y_{t}$ is an $n \times 1$ vector of variables that are integrated of order one-commonly denoted I (1), and $\varepsilon_{t}$ is an $n \times 1$ vector of innovations. Results depicted in the trace test and Maxeigenvalue test guide to decide whether long-run relationship exists or not between tea export and economic growth across Bangladesh, India and Sri Lanka.

Granger Causality scrutinizes the short-run causal association between existing series. It includes estimating two equations with VAR for LNGDP and LNTEX as presented in the equation.

$$
\begin{aligned}
& \Delta L N G D P_{t}=\sum_{i=1}^{n} \alpha_{1 i} \Delta L N T E X_{t-1}+ \\
& +\sum_{i=1}^{n} \beta_{1 i} \Delta L N G D P_{t-1}+\epsilon_{t}
\end{aligned},
$$

Table 1: Description and source of data.

\begin{tabular}{lcc}
\hline \multicolumn{1}{c}{ Data } & Unit & Source \\
\hline Total export of all products across the world & Current USD & WDI \\
Total export of all products in Bangladesh/ India/ Sri Lanka & Current USD & WDI \\
Total tea export across the world & Current USD & FAOSTAT \\
Total tea export in Bangladesh/ India / Sri Lanka & Current USD & FAOSTAT \\
Gross Domestic Product & Constant 2010 USD & WDI \\
\hline
\end{tabular}

Notes: WDI indicates World Development Indicator (https://data.worldbank.org/), while FAOSTAT denotes Food and Agriculture Organization Corporate Statistical Database(http://www.fao.org/faostat/en/\#data)

Source: Own composition 


$$
\begin{aligned}
& \Delta \text { LNTEX }_{t}=\sum_{i=1}^{n} \alpha_{1 i} \Delta L N G D P_{t-1}+ \\
& +\sum_{i=1}^{n} \beta_{1 i} \Delta L N T E X_{t-1}+\epsilon_{t}
\end{aligned}
$$

where $\mathrm{LNGDP}=$ natural logarithm of GDP, LNTEX $=$ natural logarithm of tea export, $\Delta$ is the differenced operator and $\epsilon_{t}$ denotes the error term.

Lastly, we drove the impulse response function from the VAR system. Impulse response function illuminates the mechanisms via which shock spreads over time. The impulse response function of an infinite moving average in a VAR framework looks as:

$x_{t}=\sum_{i=1}^{n} A_{j} u_{t-j}$

where $X_{t}$ refers to $(\mathrm{m} \times 1)$ vector of the variables examined, $A_{j}$ is represented as $\beta_{n} A_{j-n}$. $\beta_{\mathrm{n}}$ denotes the coefficient of the exogenous variable(s) $A_{j}$ at nth time $(j=1,2,3, \ldots, \mathrm{n})$ and $u_{t}$ denotes the shock. Now, to demonstrate the responses of conditional forecast of economic growth to tea export shock in the VAR system, the equation is expressed as:

$$
\begin{aligned}
& \Delta \text { LNGDP }_{t}=\beta_{1} \Delta \text { LNTEX }_{j-1}+\beta_{2} \Delta \text { LNTEX }_{j-2}+ \\
& +\beta_{3} \Delta L N T E X_{j-3}+\ldots+\beta_{n} \Delta L N T E X_{j-n}+u_{t-j}
\end{aligned}
$$

To determine the responses of conditional forecasts of tea export to the economic growth shock in the VAR system, this expression follows:

$$
\begin{aligned}
& \Delta L N T E X_{t}=\beta_{1} \Delta L N G D P_{j-1}+\beta_{2} \Delta L N G D P_{j-2}+ \\
& +\beta_{3} \Delta L N G D P_{j-3}+\ldots+\beta_{n} \Delta L N G D P_{j-n}+u_{t-j}
\end{aligned},
$$

where $\Delta$ is the differenced operator, LNGDP denotes natural logarithm of GDP, LNTEX indicates the natural logarithm of tea export. Moreover, an impulse response function predicts the response of a variable to shock in another variable over the period in future. Microsoft Excel and Eviews software advocated the data analysis process.

\section{Results and Discussion}

\section{Comparative advantage of tea export}

Table 2 shows the tea export competitiveness of Bangladesh, India and Sri Lanka over the year 1980-2018 from the findings of the Revealed Symmetric Comparative Advantage index. It is evident from results that, over the last 40 years, Bangladesh is gradually losing its comparative advantage in tea export. In 1980, Bangladesh (0.951), India (0.993), and Sri Lanka (0.966) experienced roughly equal degrees of comparative advantage in tea export. However, since then, Bangladesh has lost its tea export potential in the international market. However, India and Sri Lanka have noticeably managed to keep their export performance high. Bangladesh

\begin{tabular}{|c|c|c|c|c|c|c|c|c|c|}
\hline Year & $\begin{array}{l}\text { Survivor } \\
\text { function }\end{array}$ & $\begin{array}{c}\text { RSCA } \\
\text { Bangladesh }\end{array}$ & $\begin{array}{c}\text { RSCA } \\
\text { India }\end{array}$ & $\begin{array}{c}\text { RSCA } \\
\text { Sri } \\
\text { Lanka }\end{array}$ & Year & $\begin{array}{l}\text { Survivor } \\
\text { function }\end{array}$ & $\begin{array}{c}\text { RSCA } \\
\text { Bangladesh }\end{array}$ & $\begin{array}{l}\text { RSCA } \\
\text { India }\end{array}$ & $\begin{array}{c}\text { RSCA } \\
\text { Sri } \\
\text { Lanka }\end{array}$ \\
\hline 1980 & 0.974 & 0.951 & 0.966 & 0.993 & 2000 & 0.462 & 0.732 & 0.900 & 0.993 \\
\hline 1981 & 0.949 & 0.960 & 0.964 & 0.993 & 2001 & 0.436 & 0.419 & 0.884 & 0.993 \\
\hline 1982 & 0.923 & 0.965 & 0.952 & 0.993 & 2002 & 0.410 & 0.316 & 0.851 & 0.993 \\
\hline 1983 & 0.897 & 0.961 & 0.952 & 0.992 & 2003 & 0.385 & 0.583 & 0.842 & 0.993 \\
\hline 1984 & 0.872 & 0.976 & 0.948 & 0.992 & 2004 & 0.359 & 0.705 & 0.823 & 0.994 \\
\hline 1985 & 0.846 & 0.959 & 0.955 & 0.992 & 2005 & 0.333 & 0.692 & 0.786 & 0.994 \\
\hline 1986 & 0.821 & 0.946 & 0.955 & 0.992 & 2006 & 0.308 & 0.554 & 0.779 & 0.991 \\
\hline 1987 & 0.795 & 0.945 & 0.953 & 0.993 & 2007 & 0.282 & 0.367 & 0.772 & 0.991 \\
\hline 1988 & 0.769 & 0.957 & 0.947 & 0.994 & 2008 & 0.256 & 0.407 & 0.759 & 0.995 \\
\hline 1989 & 0.744 & 0.946 & 0.951 & 0.993 & 2009 & 0.231 & 0.209 & 0.724 & 0.994 \\
\hline 1990 & 0.718 & 0.935 & 0.952 & 0.993 & 2010 & 0.205 & -0.183 & 0.692 & 0.994 \\
\hline 1991 & 0.692 & 0.948 & 0.949 & 0.993 & 2011 & 0.179 & -0.487 & 0.736 & 0.994 \\
\hline 1992 & 0.667 & 0.938 & 0.938 & 0.991 & 2012 & 0.154 & -0.504 & 0.694 & 0.994 \\
\hline 1993 & 0.641 & 0.932 & 0.924 & 0.987 & 2013 & 0.128 & -0.709 & 0.686 & 0.993 \\
\hline 1994 & 0.615 & 0.946 & 0.923 & 0.985 & 2014 & 0.103 & -0.410 & 0.659 & 0.994 \\
\hline 1995 & 0.589 & 0.914 & 0.925 & 0.991 & 2015 & 0.077 & -0.733 & 0.691 & 0.992 \\
\hline 1996 & 0.564 & 0.896 & 0.899 & 0.993 & 2016 & 0.051 & -0.693 & 0.658 & 0.991 \\
\hline 1997 & 0.538 & 0.872 & 0.926 & 0.993 & 2017 & 0.026 & -0.486 & 0.630 & 0.991 \\
\hline 1998 & 0.513 & 0.880 & 0.916 & 0.992 & 2018 & 0.000 & -0.658 & 0.627 & 0.990 \\
\hline 1999 & 0.487 & 0.887 & 0.903 & 0.992 & & & & & \\
\hline
\end{tabular}
lost its comparative advantage in tea export since the year 2010 when its RSCA value went below 0. It follows from this that tea export from Bangladesh failed to keep pace with other competitors in the global market. Moreover, while con-

Table 2: RSCA index and Kaplan-Meier survival rates for Bangladesh, India and Sri Lanka. 
centrating on the overwhelming domestic demand, Bangladesh tea firms failed to adopt updated knowledge, information and strategies, a failure that reduced the country's tea export opportunities abroad (Blomstermo et al., 2004). This finding for Bangladesh is in line with the previous study of Suprihatini (2005) which focuses on Indonesia.

India, on the contrary, is enjoying a comparative advantage in tea export over the same period. Admittedly, the RSCA value has contracted gradually, implying that India has diversified its export sectors (The Economic Times, 2016). Yet, India is sustaining its position in the worldwide tea market. This is because of its active involvement of Indian tea board with the country's tea industries. The tea board is carrying out different promotional activities aimed at improving the production, consumption and boosting the international trade demand of tea (Navitha and Sethurajan, 2018). The promotional activities include a Darjeeling charity auction, attendance at major trade events, tea seminar and contests, publicity through social media, print media and websites, and a patronage programme (Navitha and Sethurajan, 2018). This result is in line with the findings of Nugrahaningrum et al. (2020), who have explored the strong position of Indonesian tea in the world market.

Meanwhile, Sri Lanka's RSCA value has always been above 0.98 over the last 40 years, which indicates Sri Lanka's specialisation in tea production and export was consistent. It also symbolises that Sri Lanka has been able to capture its global tea demand with technological progression. The RSCA values in the recent scenario of 2018 for Bangladesh, Sri Lanka, and India are $-0.65,0.99$, and 0.62 , respectively. These values are notifying that, at present, except for Bangladesh, Sri Lanka and India enjoy a comparative advantage in tea export. It is a matter of concern that since 2010, Bangladesh has drastically lost its competitiveness in tea export. This may be due to the overwhelming domestic demand. Low-quality tea may be another contributing factor.

Meanwhile, India and Sri Lanka, after meeting their local demand, still managed to keep their export performance high, ensuring decent quality. A finding parallel to this outcome, extrapolated by Pascucci (2018), in the case of coffee export of Switzerland, was found to be highly competitive. Table 2 also provides insights on the survival rate of tea export for these countries. Bangladesh enjoyed comparative advantage in tea export from 1980 to 2009 . Since then, its RSCA value went below 0 and tea export competitiveness failed to survive. On the other hand, both India and Sri Lanka experienced an RSCA value above 0 over the entire period. This indicates that India and Sri Lanka consistently survived in their tea exporting endeavours. It also worth noting that the survival times of the analysed RSCA index in the tea trade are not persistent over the study period (Table 2). Survival chances of $97 \%$ at the start of the period fell to $0 \%$ by 2018 , implying stiff competition in the tea trade of the selected countries. Similar results also found regarding the European ham trade (Török and Jámbor, 2016) and global beer trade (Török et al., 2020).

However, standard deviations of the RSCA indices over the whole study period are quite high (0.609) for Bangladesh, suggesting variation from year to year, and they seem to remain relatively unstable over the entire period. Besides, the declining tea export trend of Bangladesh is indicating that Bangladesh's tea export is unstable over the period. Comparing to Bangladesh, the RSCA indices are relatively stable in the case of India. Although, earlier in 1980, India scored an extraordinary RSCA value, it gradually diminished over the years. This signifies that despite being competitive, India experienced instability in tea export. The results on instability in tea export for Bangladesh and India point towards a lack of innovation and a lack of technological adoption (Pascucci, 2018). However, Sri Lanka's tea export competitiveness was stable over the years as its RSCA value has always kept the same trend and the value of standard deviation is very low (0.001).

\section{Nexus between tea export and economic growth}

This paper hypothesises that tea export affects the economic growth of the selected countries. We proceed to stepby-step econometric analysis in an effort to identify whether the tea export has significant effect on the economic growth of the selected three countries. In the first step, like every time series analysis, we conducted the unit root test where the null hypothesis is that time series has a unit root. Table 3 illustrates the outcome of the ADF test for checking stationarity. Results revealed that all variables of Bangladesh, India and Sri Lanka were non-stationary, implying that p-value was greater than 0.05 . Consequently, we cannot reject the null hypothesis. Since, the variables are non-stationary, we transformed those in the first difference to make stationary. However, the results in Table 3 show that first difference p-value of economic growth and tea export is smaller than 0.05 . Hence, we reject the null hypothesis and therefore, these variables do not have a unit root, meaning that the time series is stationary. Given the findings, we ran Johansen Cointegration, Granger causality, and Impulse Response Function.

Table 3: ADF test results.

\begin{tabular}{|c|c|c|c|c|c|c|}
\hline \multicolumn{7}{|c|}{ Augmented Dickey-Fuller test with t-statistic } \\
\hline \multirow[b]{2}{*}{ Variable } & \multicolumn{2}{|c|}{ Bangladesh } & \multicolumn{2}{|c|}{ India } & \multicolumn{2}{|c|}{ Sri Lanka } \\
\hline & Level & $1^{\text {st }}$ Diff. & Level & $1^{\text {st }}$ Diff. & Level & $1^{\text {st }}$ Diff. \\
\hline LNGDP & $\begin{array}{c}0.795 \\
(0.999)\end{array}$ & $\begin{array}{l}-9.509 * * * \\
(0.000)\end{array}$ & $\begin{array}{l}-2.220 \\
(0.465)\end{array}$ & $\begin{array}{c}-10.586 * * * \\
(0.000)\end{array}$ & $\begin{array}{l}-1.483 \\
(0.817)\end{array}$ & $\begin{array}{l}-4.673 * * * \\
(0.003)\end{array}$ \\
\hline LNTEX & $\begin{array}{l}-3.024 \\
(0.139)\end{array}$ & $\begin{array}{l}-5.179 * * * \\
(0.001)\end{array}$ & $\begin{array}{l}-2.453 \\
(0.348)\end{array}$ & $\begin{array}{l}-6.691 * * * \\
(0.000)\end{array}$ & $\begin{array}{l}-3.488 \\
(0.060)\end{array}$ & $\begin{array}{l}-5.577 * * * \\
(0.000)\end{array}$ \\
\hline
\end{tabular}

*** Denotes rejection of null hypothesis at 1 percent level of significance and p-values in the parenthesis

Source: Authors' calculations using Eviews 
Firstly, we conduct Johansen Cointegration test to explore the cointegration between tea export and economic growth. The outcomes of Johansen Cointegration test are presented in Table 4 to make decision regarding long-run relationship. The Trace statistic and Max-Eigen statistic for Bangladesh, India, and Sri Lanka remain well inside the 0.05 critical values. Also, p-values obtained from trace statistic and MaxEigen statistic results ascertain that all the null hypotheses of no cointegrating equation defined for Bangladesh, India, and Sri Lanka are accepted. In other words, economic growth and tea export do not move together in the long-run and they do not affect each other in the long-run. Therefore, we infer that no long-run relationship exists between economic growth and tea export in any of the cases of Bangladesh, India, and Sri Lanka. This outcome is apparent for Bangladesh since Bangladesh lost its export competitiveness in recent years as visible from the above. However, having a strong position in the international tea market with the bulk of tea export, the case of India and Sri Lanka seems unusual. The reason behind there being no long-run relationship between tea export and economic growth may be an inability to use resources efficiently, not getting a fairer price, a higher cost of production (Krishna, 2019; Hilal et al., 2020), or maybe the unstructured tea industry.

Next, we illuminate the short-run causality inter-linkages between economic growth and tea export (Table 5). As evident from the findings, in the short-run, no directional cau- sality runs between economic growth and tea export across Bangladesh and India, connoting that economic growth and tea export do not substantiate any short-run effect on each other. However, in Sri Lanka, evidence of unidirectional causality signifies that tea export causes short-run economic growth. A similar type of finding was revealed from the study of Chantal et al. (2018), where they found that tea export affects the GDP of Rwanda. Hence, although no causal relationship exists in the long-run, tea export is vital for the Sri Lankan economy since it contributes to the short-run growth of Sri Lanka. The finding revealed for Sri Lanka supports the export-led growth hypothesis in the short-run. Similar short-run findings for the case of citrus export were revealed by Bakari (2018) in Tunisia. The outcome suggests that a structured frame of action and long-term policy implications can drive Sri Lanka's tea export to the long-run economic growth. Besides, Fair Trade International Certification should be in action, which gives international recognition in global market and higher prices of their tea products, as well as professional international and local advice to uphold best practices and boost the economic growth in the long run.

The reason behind Bangladesh and India failing in promoting economy through tea export may be due to several factors. Firstly, low degree of institutional quality. Instituitional quality as a proxy for a good economic institutional quality helps achieve the export-led growth hypothesis (Sathyamoorthy and Cheong, 2019). Secondly, adopting

Table 4: Johansen Cointegration test.

\begin{tabular}{|c|c|c|c|c|}
\hline \multicolumn{5}{|c|}{ Unrestricted Cointegration Rank Test (Trace) } \\
\hline Country & $\begin{array}{l}\text { Hypothesized } \\
\text { no. of CE(s) }\end{array}$ & $\begin{array}{c}\text { Trace } \\
\text { statistic }\end{array}$ & 0.05 critical value & Prob. \\
\hline \multirow{2}{*}{ Bangladesh } & None & 12.848 & 15.494 & 0.123 \\
\hline & At most 1 & 1.247 & 3.841 & 0.153 \\
\hline \multirow{2}{*}{ India } & None & 13.836 & 15.494 & 0.087 \\
\hline & At most 1 & 1.2469 & 3.841 & 0.264 \\
\hline \multirow{2}{*}{ Sri Lanka } & None & 11.038 & 15.494 & 0.209 \\
\hline & At most 1 & 0.955 & 3.841 & 0.328 \\
\hline \multicolumn{5}{|c|}{ Unrestricted Cointegration Rank Test (Max Eigenvalue) } \\
\hline & $\begin{array}{c}\text { Hypothesized } \\
\text { no. of CE(s) }\end{array}$ & Max-Eigen statistic & 0.05 critical value & Prob. \\
\hline \multirow{2}{*}{ Bangladesh } & None & 13.801 & 14.264 & 0.119 \\
\hline & At most 1 & 1.047 & 3.841 & 0.173 \\
\hline \multirow{2}{*}{ India } & None & 12.589 & 14.264 & 0.090 \\
\hline & At most 1 & 1.246 & 3.841 & 0.264 \\
\hline \multirow{2}{*}{ Sri Lanka } & None & 10.082 & 14.264 & 0.206 \\
\hline & At most 1 & 0.955 & 3.841 & 0.328 \\
\hline
\end{tabular}

Source: Authors' calculation using Eviews.

Table 5: Granger causality test for Bangladesh, India and Sri Lanka

\begin{tabular}{|c|c|c|c|c|}
\hline Country & \begin{tabular}{|l} 
Null hypothesis \\
\end{tabular} & F-statistic & Prob. & Decision \\
\hline \multirow{2}{*}{ Bangladesh } & $\Delta$ LNTEX does not cause $\Delta$ LNGDP & 1.194 & 0.316 & \multirow{2}{*}{ No short-run directional causality } \\
\hline & $\Delta$ LNGDP does not cause $\Delta$ LNTEX & 0.261 & 0.771 & \\
\hline \multirow{2}{*}{ India } & $\Delta$ LNTEX does not cause $\Delta$ LNGDP & 0.119 & 0.731 & \multirow{2}{*}{ No short-run directional causality } \\
\hline & $\Delta$ LNGDP does not cause $\Delta$ LNTEX & 0.264 & 0.610 & \\
\hline \multirow{2}{*}{ Sri Lanka } & $\Delta$ LNTEX does not cause $\Delta$ LNGDP & 2.507 & $0.047 * *$ & \multirow{2}{*}{$\begin{array}{l}\text { Unidirectional causality from tea } \\
\text { export to economic growth }\end{array}$} \\
\hline & $\Delta$ LNGDP does not cause $\Delta$ LNTEX & 0.530 & 0.593 & \\
\hline
\end{tabular}

** Denotes rejection of null hypothesis at 5 percent level of significance.

Source: Authors' calculation using Eviews 
inward-looking policies causes resources to shift in the industries that only produce for domestic markets (Dawson, 2005). The result for Bangladesh and India having no long-run and short-run impact of tea export on the economic growth is in line with the study of Levin and Raut (1997), where they found that export of primary commodities or agricultural commodities do not significantly affect economic growth. Similar result was unveiled by Gilbert (2013) for cocoa export of Cameron as no impact on economic growth was found. Moreover, the interpretation of Faridi (2012) also claimed that agricultural export does not have any positive impact on the economic growth.

Finally, using the impulse response function, the study shows the effect of any shock generated in the tea export and economic growth on each other. As of Bangladesh, according to Figure 1, with one standard deviation shock to LNTEX, LNGDP faces a slight decay till the second period in the future. However, after the second period, the shock generated from LNTEX leads to a surge in LNGDP, as it reaches its peak in the third period. Further, LNGDP's response starts to deteriorate until it passes the fourth period. Later in the fourth period, a shock given by LNTEX becomes mild, and LNGDP stays positive and dormant throughout the future periods. It demonstrates that uncertainty in tea export leads to a slight fallout in economic growth till the second period onwards, and then economic growth reaches its peak in the third period and then goes downward again. It follows that a shock to tea export becomes lenient and economic growth stays static on the positive side. Moreover, a shock in LNGDP induces LTEX to drop till the second period. Following the second period, LNTEX moves upward but remains negative and for the rest of the periods in the future, this trend continues. This means a shock to economic growth tempts tea export to decrease and continues to deter tea export in Bangladesh. Therefore, we can infer that despite any uncertainty in tea export, economic growth slightly flatters in the initial stage, while uncertainty in economic growth induces tea export to shrink in the future.

In the case of India, a shock originating in tea export causes a slight spike in economic growth in the second period (Figure 2). Since the third period, its effect dissipates and adheres to the trend. Similarly, in the figure, a shock to economic growth yields the same response in tea export, and it does not fluctuate to a noticeable extent in the future. In India, therefore, the shock given separately in LNTEX and LNGDP has no significant impact on each other. Henceforth,
Response of D(LNGDP) to D(LNTEX) Innovation using Cholesky (d.f. adjusted) Factors

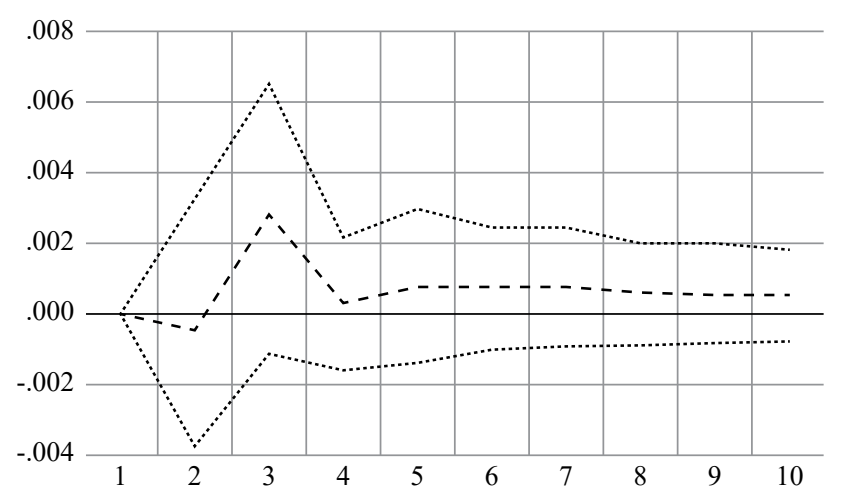

Figure 1: Impulse response function for Bangladesh. Source: Authors' composition using Eviews.

Response of D(LNGDP) to D(LNTEX) Innovation using Cholesky (d.f. adjusted) Factors

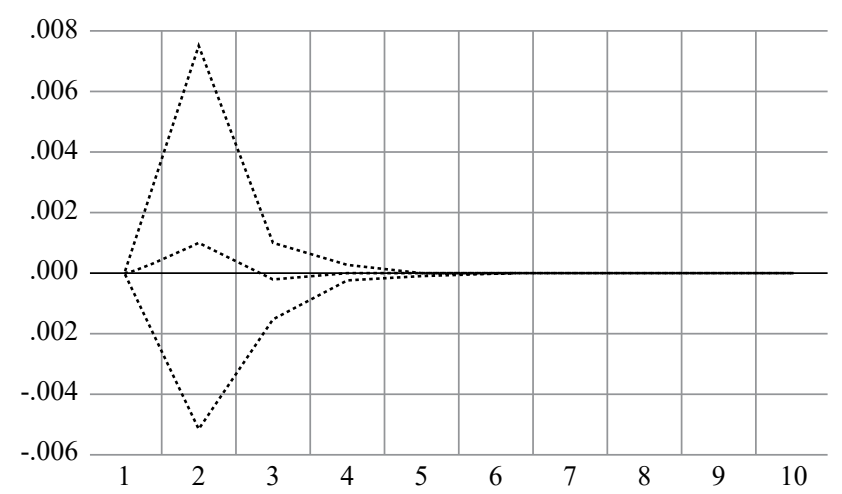

Response of D(LNTEX) to D(LNGDP) Innovation using Cholesky (d.f. adjusted) Factors

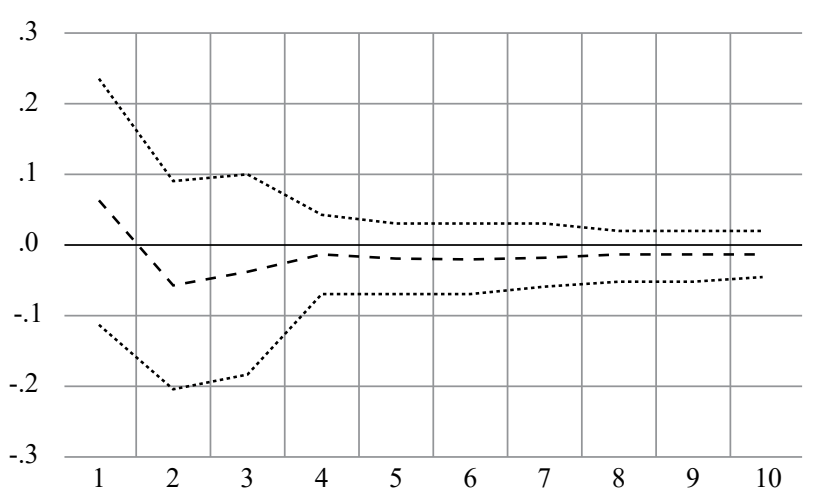

Figure 2: Impulse response function for India.

Source: Authors' composition using Eviews 
uncertainty occurred in tea export and, in the economic growth, invariably do not hurt each other in the future.

As for Sri Lanka, Figure 3 illustrates that one standard deviation shock to LNTEX leads to fluctuation in LNGDP over the period. It is discernible that any shock in tea export pushes economic growth downward till the second period onwards. Then, the economic growth bounces back in response to any shock given in tea export and reaches its peak in the third period. Economic growth again experiences drastic fallout and becomes negative in the fifth period. However, economic growth goes upward since that juncture and persists in positive direction throughout the future periods until it gets affected again in the ninth period. Moreover, Figure 3 states that tea export faces a steep descent from the first to second period, ending up touching its peak in the third period. After then tea export once again rides in the downturn and becomes stable after the seventh period. So, tea export suffers in the first two periods from shock in economic growth and becomes the highest in the third period. Since that period, tea export digests slight fallout to the seventh period in the future, after which the effect of shock in economic growth disappears. These findings reveal that tea export matter hugely to steady economic growth in Sri Lanka. This is because uncertainty in tea export causes heavy fluctuations in the country's economic growth, whereas uncertain economic growth at home also affects tea export. However, in Bangladesh and in India, uncertainty with regard to tea export does not significantly hamper future economic growth.

Consequently, we can conclude that tea export and economic growth are interlinked in Sri Lanka despite having no long-run relationship with each other. It can also be inferred that if the Sri Lankan government cannot manage to keep tea export stable and high, Sri Lanka might endure an economic depression, as can be seen in Figure 3. Nevertheless, Bangladesh and India should always try to expand tea export to earn more foreign currency, especially Bangladesh, which is losing its export competitiveness.

Response of D(LNGDP) to D(LNTEX) Innovation using Cholesky (d.f. adjusted) Factors

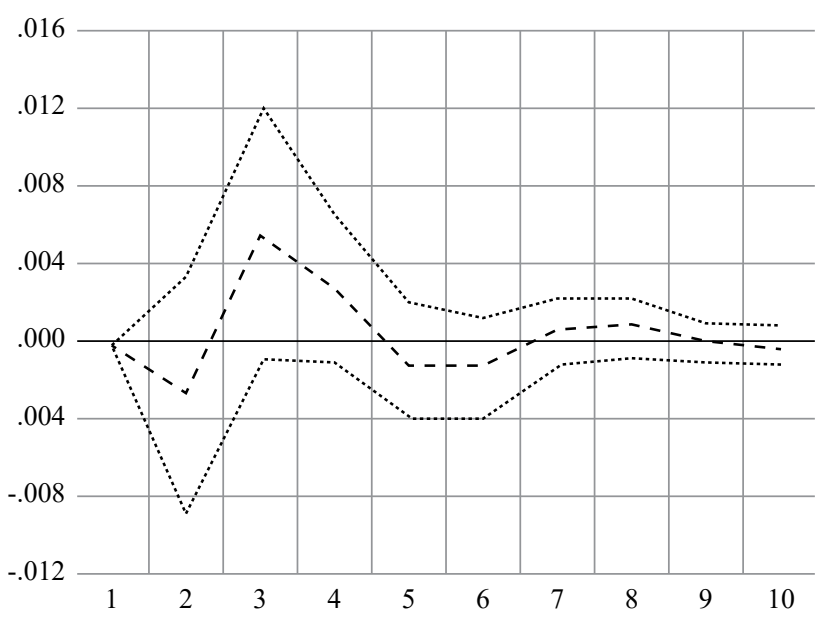

\section{Conclusions}

This article attempted to reveal the comparative advantage of tea export and dynamics between tea export and economic growth across Bangladesh, India, and Sri Lanka. Results indicated that over the last 40 years, Bangladesh lost its comparative advantage in tea export, whereas India managed to sustain its competitiveness, and Sri Lanka remained at the top with an RSCA value of 0.99 in the last couple of years. RSCA value of Bangladesh in the year 2018 was -0.65 , while India scored 0.88 and Sri Lanka mastering at 0.99. These findings validate that Sri Lanka enjoys the highest comparative advantage in tea export, whereas India remained on a positive track and Bangladesh lost its tea export potential.

Moreover, the outcomes revealed from the Johansen Cointegration test indicate that tea export and economic growth do not affect each other in the long run for Bangladesh, India and Sri Lanka. However, in the short-run, results revealed by Granger causality argue that it is solely in the case of Sri Lanka that tea export cause economic growth, in contrast to Bangladesh and India, where there is no evidence of causality between the tea export and economic growth found. Lastly, the Impulse Response Function outcomes forecast that in Bangladesh, economic growth experiences an initial spike in response to uncertainty in tea export. However, the shock dissipates quickly and does not massively affect economic growth. Interestingly, in India, neither is economic growth affected significantly by uncertainty over tea export, nor vice versa. Meanwhile, in Sri Lanka, economic growth heavily fluctuates if there is a shock to tea export, and inverse is also true. Hence, this article recommends that the Bangladesh government should eye on entering a new world tea market and expand the country's foreign earnings, whereas India should formulate a plan to improve its tea industry to lift its economy. Most importantly, Sri Lanka should redesign its policy towards tea industries because despite leading the world, as shown in the findings, the

Figure 3: Impulse response function for Sri Lanka.

Source: Authors' composition using Eviews

Response of D(LNTEX) to D(LNGDP) Innovation using Cholesky (d.f. adjusted) Factors

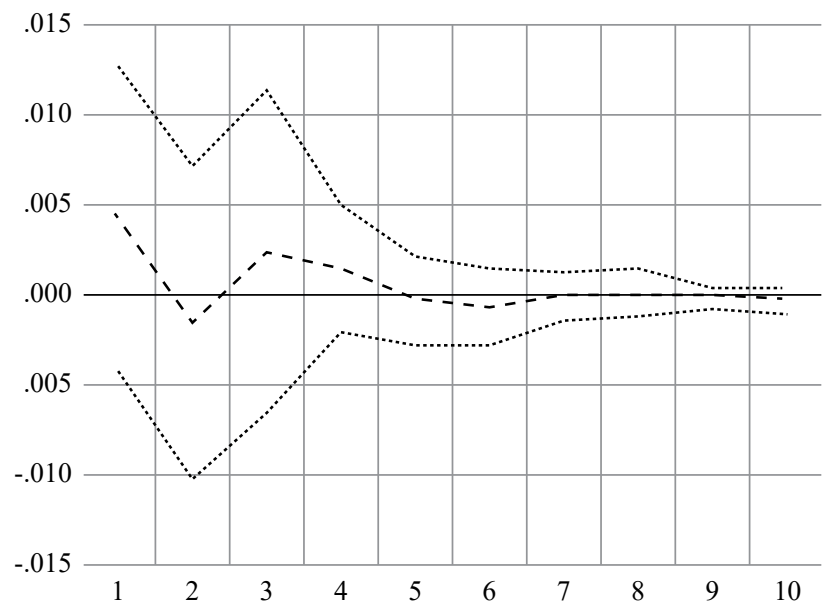


country's tea export have failed to promote economic growth in the long-run. Therefore, immediate actions are required to investigate the hindrances, not only in Sri Lanka but also for Bangladesh and India. Alongside, governments of these countries should look forward to expanding tea export since growth in agricultural exports leads to economic growth.

Nevertheless, our paper is constrained by some limitations, that may guide direction to further research avenues. First, we only incorporated Bangladesh, India and Sri Lanka in our study representing a specific region. Further research can be conducted on other major tea-producing and teaexporting countries. Second, due to data unavailability, we were not able to analyse the factors that affect tea export potential. Hence, if more data becomes available, this limitation can be addressed. Third, we only considered the relationship between tea export and economic growth. In the future, scholars may attempt to disclose the linkages between other major agricultural exporting products and economic growth from a macroeconomic perspective. Fourth, with the advent of modern econometrics and machine learning, further study can adopt updated econometric models in determining the association between agricultural export, non-agricultural export, and economic growth.

\section{References}

Adhikary, M. and Maity, S. (2010): India's tea export in the scenario of WTO: An analysis of trend and structural shift. International Journal of Indian Culture and Business Management, 3 (2), 162-180. https://doi.org/10.1504/IJICBM.2010.030752

Asiatic Society of Bangladesh (2014): Tea Industry. Banglapedia: National Encyclopedia of Bangladesh. Retrieved from: https://en.banglapedia.org/index.php?title=Tea_Industry (Accessed in January 2021).

Bakari, S. (2018): The Impact of Citrus Exports on Economic Growth: Empirical Analysis from Tunisia. International Journal of Food and Agricultural Economics (IJFAEC), 6 (1), 95-112. https://doi.org/10.22004/ag.econ.283764

Balassa, B. (1965): Trade Liberalisation and "Revealed" Comparative Advantage. The Manchester School, 33 (2), 99-123. https://doi.org/10.1111/j.1467-9957.1965.tb00050.x

Barros Jr, F., Ferreira, A. L., Marcondes, R. L. and Prioste, R. R. W. (2019): Coffee exports and industrialization in Brazil. Applied Economics Letters, 26 (9), 712-716. https://doi.org/10.1080/13 504851.2018.1489498

Basu Majumder, A., Bera, B. and Rajan, A. (2010): Tea statistics: global scenario. Inc J Tea Sci, 8 (1), 121-124.

Blomstermo, A., Eriksson, K. and Deo Sharma, D. (2004): Domestic activity and knowledge development in the internationalization process of firms. Journal of International Entrepreneurship, 2 (3), 239-258. https://doi.org/10.1023/ B:JIEN.0000032775.53005.59

Bojnec, Š. and Fertö, I. (2016): Export competitiveness of the European Union in fruit and vegetable products in the global markets. Agricultural Economics-Zemedelska Ekonomika, 62 (7), 299-310. https://doi.org/10.17221/156/2015-AGRICECON

BTB (2017): Statistical bulletin of Bangladesh tea board for the month of October. BaizidBostami Road, Chittagong, 9-11.

Canchari, N. N., Aquino Rodriguez, C. A. and Baral, P. (2018): The impact of traditional and non-traditional agricultural exports on the economic growth of Peru: a short-and long-run analysis. Studies in Agricultural Economics, 120 (3), 157-165. https://doi.org/10.7896/j.1807
CBSL (2019): Annual Report. Colombo: Central Bank of Sri Lanka. Retrieved from: https://www.cbsl.gov.lk/en/publications/economic-and-financial-reports/annual-reports/annualreport-2014 (Accessed in January 2021).

Chantal, M. M., Wei, S., Daniel, N. and Delphine, T. (2018): Contribution of Agricultural Export to Economic Growth in Rwanda: The Case of Coffee, Tea and Flowers. Journal of Economics and Trade, 3 (1) 14-24.

Dawson, P. J. (2005): Agricultural exports and economic growth in less developed countries. Agricultural Economics, 33 (2), 145-152. https://doi.org/10.1111/j.1574-0862.2005.00358.x

FAOSTAT (2017): World tea production in 2017; Crops/World Regions/Production Quantity from picklists. Rome: FAO.

Faridi, M. Z. (2012): Contribution of agricultural exports to economic growth in Pakistan. Pakistan Journal of Commerce and Social Sciences (PJCSS), 6 (1), 133-146.

Fetscherin, M. (2010): The determinants and measurement of a country brand: the country brand strength index. International Marketing Review, 27 (4), 466-479. https://doi.org/10.1108/02651331011058617

Gilbert, N. A., Linyong, S. G. and Divine, G. M. (2013): Impact of agricultural export on economic growth in Cameroon: Case of banana, coffee and cocoa. International Journal of Business and Management Review, 1 (1), 44-71.

Gunathilaka, R. D. and Tularam, G. A. (2016): The tea industry and a review of its price modelling in major tea producing countries. Journal of Management and Strategy, 7 (1), 34-39. https://doi.org/10.5430/jms.v7n1p21

Hilal, M. I. M. (2020): Sri Lanka's Tea Economy: Issues and Strategies. Journal of Politics and Law, 13 (1), 1-11. https://doi.org/10.5539/jpl.v13n1p1

Hong, L. and Song, W. (2015): Trade Competitiveness of Tea from Fujian, China: Analysis based on Porter Masonry Model. IN International conference on Engineering Management, Engineering Education and Information Technology (EMEEIT 2015). Atlantis Press. https://doi.org/10.2991/emeeit-15.2015.2

Jannat, N. (2017): Investigation of Settlement Pattern and Dwelling System of the Tea Workers' Community in Chittagong Region, Bangladesh. International Journal of Engineering and Innovative Technology, 6 (10), 19-26.

Jin, X. (2019): Analysis of Comparative advantages of tea trade between China and Countries along the "Belt and Road Initiative". IN IOP Conference Series: Earth and Environmental Science, 310 (5), 052056. IOP Publishing.

Johansen, S. (1991): Estimation and hypothesis testing of cointegration vectors in Gaussian vector autoregressive models. Econometrica: Journal of the Econometric Society, 59 (6), 1551-580. https://doi.org/10.2307/2938278

Juhász, A. and Wagner, H. (2013): An analysis of Hungarian agrifood export competitiveness. Studies in Agricultural Economics, 115 (3), 150-156. https://doi.org/10.7896/j.1311

Kamau, D. M., Spiertz, J. H. J. and Oenema, O. (2008): Carbon and nutrient stocks of tea plantations differing in age, genotype and plant population density. Plant and Soil, 307 (1), 29-39. http://doi.org/10.1007/s11104-008-9576-6

Krishna, P. (2019): The tea industry faces severe liquidity problems: Vivek Goneka ITA Chairman. BW BUSINESSWORLD. Retrieved from: https://www.businessworld.in/article/Tea-Industry-Facing-Severe-Liquidity-Problems-VivekGoenka-ITA-Chairman/23-12-2019-180961/ (Accessed in January, 2021).

Laursen, K. (2015): Revealed comparative advantage and the alternatives as measures of international specialization. Eurasian Business Review, 5 (1), 99-115. https://doi.org/10.1007/ s40821-015-0017-1

Levin, A. and Raut, L. K. (1997): Complementarities between exports and human capital in economic growth: evidence from the 
semi-industrialized countries. Economic development and cultural change, 46 (1), 155-174. https://doi.org/10.1086/452325

Muthamia, A. K. and Muturi, W. (2015): Determinants of earnings from tea export in Kenya: 1980-2011. Journal of World Economic Research, 4 (1), 15-22. https://doi.org/10.11648/j. jwer.20150401.12

Naseer, M. A. U. R., Ashfaq, M., Hassan, S., Adil, S. A. and Ariyawardana, A. (2019): Outlook on the global trade competitiveness of Pakistan's mandarin industry: An application of revealed symmetric comparative advantage framework. Outlook on Agriculture, 48 (1), 66-74. https://doi.org/10.1177\%2F0030727018817788

Navitha, B. and Sethurajan, S. (2018): The problems and prospects of Indian tea exports industries. International Journal of Research and Analytical Reviews, 5 (3), 696-700.

Nugrahaningrum, Y., Zakaria, R. and Fahma, F. (2020): Analysis of Indonesian tea competitiveness in the international market. IN AIP Conference Proceedings 2217 (1), 030067. AIP Publishing LLC. https://doi.org/10.1063/5.0000810

Olayungbo, D. O. and Quadri, A. (2019): Remittances, financial development and economic growth in sub-Saharan African countries: evidence from a PMG-ARDL approach. Financial Innovation, 5 (1), 1-25. https://doi.org/10.1186/s40854-019-0122-8

Pascucci, F. (2018): The export competitiveness of Italian coffee roasting industry. British Food Journal, 120 (7), 1529-1546. https://doi.org/10.1108/BFJ-05-2017-0306

Rahardjo, B., Akbar, B. M. B., Iskandar, Y. and Shalehah, A. (2020): Analysis and strategy for improving Indonesian coffee competitiveness in the international market. BISMA (Bisnis dan Manajemen), 12 (2), 154-167. https://doi.org/10.26740/ bisma.v12n2.p154-167

Rossato, F. G. F., Susaeta, A., Adams, D. C., Hidalgo, I. G., de Araujo, T. D. and de Queiroz, A. (2018): Comparison of revealed comparative advantage indexes with application to trade tendencies of cellulose production from planted forests in Brazil, Canada, China, Sweden, Finland and the United States. Forest Policy and Economics, 97, 59-66. https://doi.org/10.1016/j. forpol.2018.09.007

Saboniene, A. (2009): Lithuanian export competitiveness: comparison with other Baltic States. Engineering Economics, 62 (2), 49-57.

Sachitra, K. M. V., Chong, S. C. and Khin, A. A. (2016): Sources of competitive advantage measurement in the minor export Crop
Sector in Sri Lanka result from pilot study. Asian Journal of Agricultural Extension, Economics \& Sociology, 12 (2), 1-15. https://doi.org/10.9734/AJAEES/2016/27814

Sanjuán-López, A. I., and Dawson, P. J. (2010): Agricultural exports and economic growth in developing countries: A panel cointegration approach. Journal of Agricultural Economics, 61 (3), 565-583. https://doi.org/10.1111/j.1477-9552.2010.00257.x

Sathyamoorthy, V. and Cheong, T. T. (2019): Does institutional quality matter for the success -of export-led growth?. International Journal of Economics \& Management, 13 (2), 407-420.

Shah, S. W. A., Haq, M. A. and Farooq, R. M. A. (2015): Agricultural export and economic growth: A case study of Pakistan. Public Policy and Administration Research, 5 (8), 88-96.

Shalbuzov, N., Fikretzade, F. and Huseyn, R. (2020): The International Competitiveness of Azerbaijani fruit and vegetable products. Studies in Agricultural Economics, 122 (1), 51-55. https://doi.org/10.7896/j.1921

Suprihatini, R. (2005): Indonesian tea export competitiveness in the world's tea market. Jurnal Agro Ekonomi, 23 (1), 1-29.

Suresh, A. and Mathur, V. C. (2016): Export of agricultural commodities from India: Performance and Prospects. Indian Journal of Agricultural Sciences, 86 (7), 876-83.

Tea Board of India (2014): 61 ${ }^{\text {st }}$ Annual Report of Tea Board 201415. Retrieved from: http://www.teaboard.gov.in (Accessed in January, 2021).

The Economic Times (2016): India's exports better placed in product diversification. Retrieved from: https://economictimes. indiatimes.com/news/economy/foreign-trade/indias-exportsbetter-placed-in-product-diversification/articleshow/53706568. cms? from $=\mathrm{mdr}$ (Accessed in March, 2021).

Török, A. and Jámbor, A. (2016): Determinants of the revealed comparative advantages: The case of the European ham trade. Agricultural Economics Czech, 62 (10), 471-482. https://doi.org/10.17221/177/2015-AGRICECON

Török, A. and Jámbor A. (2013): Competitiveness and Geographical Indications: the case of fruit spirits in Central and Eastern European countries. Studies in Agricultural Economics, 115(1), 25-32. https://doi.org/10.7896/j.1223

Török, Á., Szerletics, Á. and Jantyik, L. (2020): Factors Influencing Competitiveness in the Global Beer Trade. Sustainability, 12(15), 5957. https://doi.org/10.3390/su12155957 